\title{
KEFEKTIFAN MODEL PROBLEM BASED INSTRUCTION (PBI) DAN MODEL SINEKTIK DALAM PEMBELAJARAN MENULIS CERPEN SISWA SEKOLAH MENENGAH PERTAMA
}

\author{
Dina Komalasari \\ Program Studi Pendidikan Bahasa dan Sastra Indonesia \\ Universitas Muhammadiyah Buton \\ Jl. Betoambari No 36 Kota Baubau Sulawesi Tenggara \\ dina_com28@yahoo.com
}

\begin{abstract}
Abstrak
Tujuan penelitian eksperimen ini adalah untuk mengetahui efektivitas model Problem Based Instruction (PBI) dan model sinektik dalam pembelajaran menulis cerita pendek pada siswa sekolah menengah pertama di suatu sekolah di Kabupaten Wakatobi, Sulawesi Tenggara. Selain itu, penelitian ini juga hendak mengetahui bagaimana perbandingan efektivitas kedua model tersebut. Melalui strategi kontrol grup pre-tes-post-tes, populasi dalam penelitian ini adalah seluruh siswa kelas VIII yang berjumlah 47 siswa. Berdasarkan hasil analisis data, penelitian ini menemukan bahwa pembelajaran menulis cerpen dengan menggunakan model PBI telah memenuhi kriteria keefektifan, begitu juga dengan pembelajaran menulis cerpen dengan menggunakan model sinektik. Hasil rata-rata nilai tes akhir siswa menunjukkan bahwa kelas yang melaksanakan pembelajaran menulis cerpen dengan menggunakan model sinektik sudah mencapai ketuntasan belajar individual.
\end{abstract}

Kata Kunci: Efektivitas; pembelajaran menulis cerpen; problem based instruction; sinektik

\begin{abstract}
The purpose of this experimental study was to determine the effectiveness of the Problem Based Instruction (PBI) model and the synectic model in learning to write short stories in one of junior high schools in Wakatobi, Southeast Sulawesi. This study also aims to compare the effectiveness of the PBI model and the synectic model. Using pre-test-post-test group control strategy, the population of this study covers all eighth grade students totaling 47 students. The results of the study show that students' learning to write short stories using the PBI model has met the effectiveness criteria as well as students' learning to write short stories using the synectic model. The
\end{abstract}


results show that the students' average final test score lead to individual learning completeness in writing short stories using the synectic model.

Keywords: Effectiveness; problem based instruction; short story writing learning; synectic.

\section{A. PENDAHULUAN}

Cerita pendek adalah salah satu ragam fiksi atau cerita rekaan yang sering disebut kisahan prosa pendek (Ismail, 2011). Cerita pendek adalah cerita fiksi yang ukurannya pendek dan ruang lingkup permasalahannya menyuguhkan sebagian kecil saja dari kehidupan tokoh yang menarik perhatian pengarang, dan keseluruhan cerita memberi kesan tunggal.

Menulis cerita pendek adalah kegiatan menuangkan kisahan atau mengisahkan satu peristiwa kehidupan yang dialami tokoh. Kegiatan ini merupakan kegiatan ekspresi sastra yang perlu diajarkan kepada siswa. Kegiatan ini bermanfaat untuk melatih siswa dalam menuangkan gagasan dan dapat mengembangkan kreativitas mereka ke dalam sebuah tulisan. Selain itu, pembelajaran menulis cerita pendek di sekolah dapat memupuk siswa yang memiliki bakat dan minat menulis untuk dibina secara khusus, supaya menjadi penulis yang andal dan profesional di masa depan. Selanjutnya, pembelajaran menulis cerpen juga bermanfaat bagi daya imajinasi siswa.

Model pembelajaran yang digunakan dalam proses pembelajaran di kelas banyak jenisnya, namun tidak semua model pembelajaran tersebut sesuai untuk digunakan dalam pembelajaran menulis cerita pendek, misalnya model Problem Based Instruction (PBI) dan model sinektik. Keduanya mempunyai ciri khas, namun merupakan model pembelajaran yang mengedepankan cara berpikir tingkat tinggi.

Arend (dalam Trianto, 2009) mengemukakan bahwa pembelajaran berdasarkan masalah atau PBI merupakan suatu pendekatan pembelajaran yang mengajarkan siswa mengerjakan permasalahan yang otentik dengan maksud untuk menyusun pengetahuan mereka sendiri, mengembangkan inkuiri, mengasah keterampilan berpikir tingkat tinggi, mengembangkan kemandirian, dan percaya diri. Model PBI merupakan sebuah model pembelajaran yang mengajak siswa untuk berpikir kritis karena model PBI menyajikan masalah otentik dan bermakna yang terjadi di sekitar siswa yang dapat memberikan kemudahan kepada mereka untuk melakukan penyelidikan dan inkuiri.

Model sinektik adalah model pembelajaran yang mengajak siswa untuk berpikir kreatif. Selain itu, kreativitas merupakan pola pengembangan mental yang baru. Komponen emosional lebih penting daripada kemampuan intelektual. Banyak pemecahan masalah yang bersifat 
rasional dan intelektual. Jika yang dibantu dengan yang irrasional dan emosional akan membangkitkan ide-ide segar.

Menurut Wagiran (2009) menulis merupakan keterampilan berbahasa yang digunakan dalam komunikasi tidak langsung. Keterampilan menulis ini tidak didapat secara alamiah, namun harus melalui proses belajar dan berlatih. Menulis bukan sebuah pekerjaan yang sulit namun juga bukan merupakan pekerjaan yang mudah. Untuk memulai menulis, seseorang tidak harus menjadi peneliti yang terampil. Akan tetapi, berlatih menulis juga tidak cukup dilakukan hanya sekali atau dua kali saja. Frekuensi berlatih menulis akan menjadikan seseorang menjadi terampil dalam kegiatan menulis. Tidak banyak orang yang dapat menulis sekali jadi karena menulis merupakan sebuah proses. Proses ini melibatkan tahap prapenulisan, penelitian, penyuntingan, dan perbaikan.

Peristiwa-peristiwa yang terjadi dalam cerpen hanya rekayasa pengarangnya. Demikian pula dengan pelaku, waktu, suasana, dan tempat terjadinya peristiwa itu pun hanya direka oleh pengarangnya. Meskipun bersifat khayal, namun cerita dalam cerpen masih masuk akal sehingga dimungkinkan untuk terjadi. Bahan baku cerpen berasal dari kisah-kisah yang benar-benar terjadi dalam masyarakat.

Willian (dalam Komaidi, 2007) menyebutkan bahwa proses kreatif seorang penulis melalui empat tahap, yaitu a) tahap persiapan dimana peneliti sudah sadar apa yang akan ditulisnya dan bagaimana menuliskannya; b) tahap inkubasi yang merupakan tahapan dimana gagasan yang telah muncul disimpan dan dipikirkan matang-matang dan ditunggu waktu yang tepat untuk menuliskannya; c) tahap inspirasi dimana gagasan dan bentuk ungkapannya telah padu; dan, d) penelitian dimana penulis segera menuangkan gagasan dalam bentuk tulisan setelah inspirasi muncul, yang kemudian direvisi. Sedangkan Supriyadi (dalam Wagiran, 2009) berpendapat bahwa penyusunan sebuah tulisan memuat empat tahap, yaitu tahap persiapan (pramenulis), tahap inkubasi, tahap eliminasi, dan tahap evaluasi. Jadi, langkah-langkah menulis kreatif cerpen adalah menemukan ide atau tema penelitian kemudian menangkap dan mematangkan ide tersebut dengan menuliskannya dalam bentuk karya sastra, dan yang terakhir adalah merevisi karya tersebut untuk mendapatkan hasil yang maksimal.

Proses kreatif adalah perubahan organisasi kehidupan pribadi sehingga proses kreatif bersifat personal. Setiap pengarang memiliki daya juang kreatif yang tidak dimiliki oleh pengarang lainnya. Dari aspek pribadi tersebut, kreativitas merupakan suatu tindakan yang muncul dari tindakan seorang penullis (pangarang) terhadap lingkungan itu akan menolong inisiatif mengulur imajinasi. Penguluran imajinasi itu menunjukkan bahwa kreativitas adalah suatu proses yang menghasilkan sesuatu yang baru. 
Kemampuan menguasai kalimat, menyusun paragraf dengan perangkaian dan pengembangan yang baik bukanlah suatu pekerjaan yang mudah. Kemampuan tersebut membutuhkan pengetahuan dan pengalaman yang cukup. Para siswa sekolah menengah pertama umumnya masih kesulitan menyusun kalimat dan paragraf sebagai bentuk penuangan ide. Sebenarnya ada banyak model pembelajaran yang bisa digunakan untuk mengatasi kesulitan tersebut, seperti model PBI dan model sinektik. Model PBI adalah model pembelajaran yang memusatkan pada masalah kehidupannya yang bermakna bagi siswa, peran guru menyajikan masalah, mengajukan pertanyaan dan memfasilitasi penyelidikan dan dialog. Sedangkan model sinektik adalah model pembelajaran yang mempertemukan berbagai macam unsur, dengan menggunakan kiasan untuk memperoleh satu pandangan baru.

Problem Based Instruction (PBI) atau dalam bahasa Indonesia dikenal dengan nama Pembelajaran Berbasis Masalah adalah model pembelajaran yang menekankan pada interaksi antara stimulus dengan respons, merupakan hubungan antara dua buah arah belajar dan lingkungan. Lingkungan memberi masukan kepada siswa berupa masalah, sedangkan sistem saraf otak berfungsi menafsirkan masukan tersebut secara efektif sehingga masalah yang dihadapi dapat diselidiki, dinilai, dianalisis, dan dicari pemecahannya dengan baik. Pengalaman siswa yang diperoleh dari lingkungan akan menjadi bahan dan materi guna memeroleh pengertian serta dapat dijadikan pedoman dan tujuan belajarnya (Dewey dalam Trianto, 2007).

Arend (dalam Trianto, 2007) mengemukakan bahwa PBI merupakan suatu pendekatan pembelajaran yang mengerjakan siswa permasalahan yang otentik dengan maksud untuk menyusun pengetahuan mereka sendiri, mengembangkan inkuiri, berketerampilan berpikir tingkat tinggi, mengembangkan kemandirian, dan percaya diri. Kelebihan dari model pembelajaran PBI adalah: a) mengembangkan pemikiran kritis; b) meningkatkan kemampuan memecahkan masalah; c) meningkatkan motivasi siswa dalam belajar; d) membantu siswa belajar untuk mentransfer pengetahuan dengan situasi baru; e) dapat mendorong siswa/mahasiswa mempunyai inisiatif untuk belajar secara mandiri; f) mendorong kreativitas siswa dalam pengungkapan penyelidikan masalah yang telah ia lakukan; g) akan terjadi pembelajaran bermakna; h) siswa mengintegrasikan pengetahuan dan ketrampilan secara simultan dan mengaplikasikannya dalam konteks yang relevan; dan, i) dapat meningkatkan kemampuan berpikir kritis, menumbuhkan inisiatif siswa/mahasiswa dalam bekerja, motivasi internal untuk belajar, dan dapat mengembangkan hubungan interpersonal dalam bekerja kelompok. 
PBI terdiri atas lima fase dan perilaku. Fase-fase dan perilaku tersebut merupakan tindakan berpola yang diciptakan agar hasil pembelajaran berdasarkan masalah dapat diwujudkan. Sintak PBI dijelaskan sebagai berikut (Suprijono, 2009). Kelima fase berikut menjelaskan tentang fasefase sintak PBI dan perilaku guru dalam kegiatan belajar mengajar.

\section{Tabel 1. Sintak problem based instruction (PBI)}

\begin{tabular}{ll}
\hline \multicolumn{1}{c}{ Fase-fase } & \multicolumn{1}{c}{ Perilaku guru } \\
\hline $\begin{array}{l}\text { Fase 1: memberikan } \\
\text { orientasi tentang } \\
\text { permasalahan kepada peserta } \\
\text { didik }\end{array}$ & $\begin{array}{l}\text { Guru menyampaikan tujuan pembelajaran, menjelaskan } \\
\text { berbagai kebutuhan logistik, dan memotivasi siswa untuk } \\
\text { terlibat dalam kegiatan mengatasi masalah }\end{array}$ \\
$\begin{array}{l}\text { Fase 2: mengorganisasikan } \\
\text { peserta didik untuk meneliti }\end{array}$ & $\begin{array}{l}\text { Guru membantu peserta didik mendefinisikan dan } \\
\text { mengorganisasikan tugas-tugas belajar terkait dengan } \\
\text { permasalahannya }\end{array}$ \\
$\begin{array}{ll}\text { Fase 3: membantu investigasi } \\
\text { mandiri dan kelompok }\end{array}$ & $\begin{array}{l}\text { Guru mendorong peserta didik untuk mendapatkan informasi } \\
\text { yang tepat, melaksanakan eksperimen, dan mencari } \\
\text { penjelasan dan solusi }\end{array}$ \\
$\begin{array}{l}\text { Fase 4: mengembangkan dan } \\
\text { menyajikan hasil karya }\end{array}$ & $\begin{array}{l}\text { Guru membantu peserta didik dalam merencanakan dan } \\
\text { menyiapkan karya yang sesuai, seperti laporan, rekaman } \\
\text { video, dan lain-lain }\end{array}$ \\
$\begin{array}{l}\text { Fase 5: menganalisis dan } \\
\text { mengevaluasi proses }\end{array}$ & $\begin{array}{l}\text { Guru membantu peserta didik melakukan refleksi } \\
\text { terhadap investigasinya dan proses-proses yang mereka } \\
\text { gunakan }\end{array}$ \\
\hline
\end{tabular}

Sinektik adalah pendekatan baru yang menarik untuk perkembangan kreativitas yang dipelopori oleh Willian J. J. Gordon. Awalnya, Gordon menggunakan prosedur-prosedur sinektik untuk kelompok-kelompok kreativitas dalam organisasi industri. Beberapa tahun belakangan ini, Gordon mengadaptasi sinektik untuk digunakan pada anak-anak sekolah dan material-material yang banyak memuat aktivitas-aktivitas sinektik yang sekarang dipublikasikan (Nurimani, 2008).

Prinsip yang harus dipegang guru dalam menggunakan model sinektik adalah: a) tidak membatasi pengalaman yang mungkin diperoleh siswa; b) menghormati gagasan yang muncul; c) tidak menakuti siswa dengan hal ujian; d) membiarkan imajinasi siswa berkembang tanpa ada batasan; e) memberikan ruang untuk beradu pendapat; dan, f) memancing ide-ide kreatif dan produktif mereka.

Model sinektik terdiri atas enam tahapan. Tahapan-tahapan tersebut merupakan tindakan berpola yang diciptakan agar hasil pembelajaran sesuai dengan yang diharapkan. Tabel 2 di bawah ini menjelaskan tentang tahapantahapan pembelajaran model sinektik mulai dari tahap pertama sampai tahap 
keenam. Tahapan-tahapan tersebut menjelaskan tentang pendeskripsian kondisi awal siswa sampai siswa mampu menganalogikan masalahnya sebagai pengalaman. Sintak model sinektik dijelaskan sebagai berikut.

Tabel 2 Sintak pembelajaran model sinektik

\begin{tabular}{ll}
\hline $\begin{array}{l}\text { Tahap pertama } \\
\text { Mendeskripsikan kondisi saat ini }\end{array}$ & $\begin{array}{l}\text { Tahap kedua } \\
\text { Analogi langsung (1) }\end{array}$ \\
$\begin{array}{l}\text { Guru menyuruh siswa } \\
\text { mendeskripsikan situasi atau topik } \\
\text { yang mereka lihat saat ini. }\end{array}$ & $\begin{array}{l}\text { Siswa mengemukakan analogi langsung } \\
\text { salah satu diseleksi, dikembangkan. }\end{array}$ \\
Tahap ketiga & \\
Analogi personal & Tahap keempat \\
Para siswa "menjadi" analogi yang & Konflik yang dipadatkan \\
telah mereka seleksi di fase kedua & Berdasarkan fase kedua dan fase ketiga \\
(analogi personal). & $\begin{array}{l}\text { siswa mengemukakan konflik } \\
\text { (pertentangan) dan dipilih salah satu }\end{array}$ \\
& $\begin{array}{l}\text { untuk diangkat menjadi topik (tahap } \\
\text { penekanan konflik). }\end{array}$ \\
$\begin{array}{l}\text { Tahap kelima } \\
\text { Analogi langsung (2) }\end{array}$ & $\begin{array}{l}\text { Tahap keenam } \\
\text { Meninjau tugas yang seharusnya }\end{array}$ \\
$\begin{array}{l}\text { Siswa mengembangkan dan } \\
\text { menyeleksi analogi langsung yang lain } \\
\text { berdasar konflik pada tahap keempat. }\end{array}$ & $\begin{array}{l}\text { Guru meminta siswa meninjau kembali } \\
\text { tugas dan masalah yang sebenarnya } \\
\text { menggunakan analogi pemecahan }\end{array}$ \\
& terakhir sehingga masuk sebagai \\
pengalaman sinektik.
\end{tabular}

(Hastuti, 1996: 156-157)

Dalam penelitian ini, kemampuan siswa dalam menulis cerpen masih dianggap kurang sehingga peneliti ingin menguji efektivitas model PBI dan model sinektik. Tujuan penelitian yang ingin dicapai dalam penelitian ini adalah untuk mengetahui efektivitas model PBI dalam pembelajaran menulis cerita pendek pada kelas A. Selain itu, penelitian ini juga untuk mengetahui efektivitas model sinektik dalam pembelajaran menulis cerita pendek pada kelas B. Disamping itu, penelitian ini juga hendak mengetahui perbandingan efektivitas model PBI dan sinektik.

\section{B. METODE PENELITIAN}

Penelitian ini menggunakan metode eksperimen dengan desain penelitian yang digunakan peneliti adalah kontrol grup pre-tes-post-tes. Skenario yang dijalankan yaitu Kelas A menjadi kelas eksperimen dengan menggunakan kelas B sebagai kelas kontrol.

Populasi dalam penelitian ini adalah seluruh siswa kelas VIII di SMP Negeri Satap Wawotimu Kabupaten Wakatobi berjumlah 47 siswa. Kelas 
ini dipilih karena kelas VIII ini memiliki kemampuan berbahasa Indonesia yang setara. Rincian siswa selengkapnya disajikan pada tabel di bawah ini.

Tabel 4. Populasi penelitian

\begin{tabular}{cccc}
\hline \multirow{2}{*}{ Kelas } & \multicolumn{2}{c}{ Jenis Kelamin } & Jumlah \\
& Laki-laki & Perempuan & \\
\hline Kelas VIII A & 9 & 15 & 24 \\
Kelas VIII B & 11 & 12 & 23 \\
\hline Jumlah & $\mathbf{2 0}$ & $\mathbf{2 7}$ & $\mathbf{4 7}$ \\
\hline
\end{tabular}

Dalam penelitian ini, pengambilan sampel dilakukan dengan cara wawancara dengan pihak sekolah/guru guna penentuan lokasi penelitan. Setelah itu dipilihlah kelas VIII karena semua kelas VIII di sekolah tersebut telah mendapat materi pembelajaran menulis cerpen. Berdasarkan hasil uji homogenitas pre-test pembelajaran menulis cerpen, kelas VIII di sekolah tersebut merupakan populasi yang homogen. Kelas A menjadi kelas eksperimen, sedangkan kelas B sebagai kelas kontrol.

Penelitian yang membandingkan keefektifan model pembelajaran antara model PBI dengan model sinektik dan dilaksanakan di sekolah tersebut dengan pertimbangan: a) keterampilan menulis cerpen merupakan salah satu kompetensi dasar bahasa Indonesia SMP yang terdapat dalam Kurikulum Tingkat Satuan Pendidikan; b) proses pengajaran menulis cerpen di kelas VIII di sekolah tersebut masih menerapkan model klasikal yang kurang disenangi siswa; dan, c) untuk mencari keefektifan model pembelajaran PBI dan model sinektik yang diharapkan dapat digunakan sebagai alternatif model pembelajaran dalam pembelajaran menulis cerpen berdasarkan pengalaman orang lain.

\section{HASIL PENELITIAN}

Hasil penelitian yang dipaparkan ini berkaitan dengan fokus penelitian yaitu efektivitas model PBI dalam pembelajaran menulis cerpen pada kelas A, efektivitas model sinektik dalam pembelajaran menulis cerpen pada kelas $\mathrm{B}$, dan perbandingan efektivitas model PBI dan model sinektik.

\section{Analisis Data Pre-test}

Hasil pre-test merupakan hasil kemampuan siswa menulis cerpen berdasarkan pengalaman orang lain sebelum dikenai perlakuan pembelajaran menulis cerpen dengan menggunakan model PBI pada kelas VIII A dan sebelum dikenai perlakuan pembelajaran menulis cerpen dengan menggunakan model sinektik pada kelas VIII B. Adapun hasil pre- 
test menulis cerpen berdasarkan pengalaman orang lain dapat dilihat pada tabel berikut.

Tabel 5 Hasil pre-test menulis cerpen berdasarkan pengalaman orang lain

\begin{tabular}{lcc}
\hline \multicolumn{1}{c}{ Hasil tes } & $\begin{array}{c}\text { Kelas model Problem } \\
\text { Based Instruction (PBI) }\end{array}$ & Kelas model sinektik \\
\hline Nilai Tertinggi & 85 & 86 \\
Nilai Terendah & 5 & 58 \\
Rata-rata & 68,853 & 73 \\
Modus & 6 & 67 \\
Simpangan baku & 8, & 8,17 \\
\hline
\end{tabular}

Hasil pre-tes menulis cerpen berdasarkan pengalaman orang lain berdasarkan hasil uji homogenitas perhitungannya dapat dilihat pada tabel berikut.

Tabel 6 Hasil uji homogenitas

\begin{tabular}{|c|c|c|c|c|}
\hline \multicolumn{5}{|c|}{ Statistik } \\
\hline Sumber & $S^{2}$ & $F_{\text {hitung }}$ & $F_{\text {tabel }}$ & Status \\
\hline Kelas PBI & 72.37 & 1,083 & 2,07 & Homogen \\
\hline Kelas Sinektik & 66.83 & 1,083 & 2,07 & Homogen \\
\hline
\end{tabular}

Hasil uji homogenitas menunjukkan bahwa kelas PBI lebih besar nilainya daripada kelas sinektik.

Tabel 7 Hasil uji normalitas pre-test

\begin{tabular}{clccc}
\hline \multirow{2}{*}{ No. } & \multirow{2}{*}{ Distribusi Data Variabel } & \multicolumn{2}{c}{ Statistik } & Status \\
& & $X_{\text {hit }}^{2}$ & $X_{\text {tab }}^{2}$ & \\
\hline 1. & Kelas PBI & 10,147 & 11,07 & Normal \\
2. & Kelas sinektik & 5,648 & 11,07 & Normal \\
\hline
\end{tabular}

Hasil uji normalitas pre-tes menunjukkan bahwa kelas PBI lebih besar nilainya daripada kelas sinektik.

Tabel 8 Hasil uji normalitas pre-test

\begin{tabular}{llccc}
\hline \multirow{2}{*}{ No. } & \multirow{2}{*}{ Distribusi Data Variabel } & \multicolumn{2}{c}{ Statistik } & Status \\
& & $X_{\text {hit }}^{2}$ & $X_{\text {tab }}^{2}$ & \\
\hline 1. & Kelas PBI & 10,147 & 11,07 & Normal \\
2. & Kelas sinektik & 5,648 & 11,07 & Normal \\
\hline
\end{tabular}


Hasil uji normalitas pre-tes menunjukkan bahwa kelas PBI lebih besar nilainya daripada kelas sinektik.

Tabel 9 Hasil uji pre-test

\begin{tabular}{lccc}
\hline \multicolumn{1}{c}{ Kelas } & Rata-rata & Thitung & T (1-1/2a)(n1+n2-2) \\
\hline $\begin{array}{l}\text { Problem Based Instruction } \\
\text { (PBI) }\end{array}$ & 68,85 & & $\pm 2,00$ \\
Sinektik & 73 & $-1,982$ & \\
\hline
\end{tabular}

Hasil uji pre-tes menunjukkan bahwa kelas sinektik lebih besar nilainya daripada kelas PBI. Rata-rata nilai PBI sebesar 68,85 sedangkan sinektik 73.

Tabel 10 Hasil post-test menulis cerpen berdasarkan pengalaman orang lain

\begin{tabular}{lcc}
\hline \multicolumn{1}{c}{ Hasil tes } & $\begin{array}{c}\text { Kelas model Problem } \\
\text { Based Instruction }(\boldsymbol{P B I})\end{array}$ & Kelas model sinektik \\
\hline Nilai Tertinggi & 91 & 92 \\
Nilai Terrendah & 55 & 75 \\
Rata-rata & 77,147 & 83,40 \\
Modus & 80 & 90 \\
Simpangan baku & 8,14 & 5,67 \\
\hline
\end{tabular}

Hasil pos-tes menulis cerpen berdasarkan pengalaman orang lain menunjukan bahwa nilai tertinggi adalah kelas sinektik dibandingkan dengan nilai PBI.

Tabel 11 Hasil uji homogenitas

\begin{tabular}{ccccc}
\hline \multirow{2}{*}{ Sumber } & \multicolumn{4}{c}{ Stat } \\
$\boldsymbol{S}^{\mathbf{2}}$ & $\boldsymbol{F}_{\text {hitung }}$ & $\boldsymbol{F}_{\text {tabel }}$ & Status \\
\hline Kelas PBI & 66.25 & 2,063 & 2,07 & Homogen \\
Kelas Sinektik & 32.11 & 2,063 & 2,07 & Homogen \\
\hline
\end{tabular}

Sedangkan hasil uji homogenitas nilai PBI lebih besar dibandingkan dengan kelas sinektik. Pemerolehan nilai PBI 66,25 sedangkan sinektik 32,11 .

Tabel 12 Hasil uji normalitas post-test

\begin{tabular}{clccc}
\hline \multirow{2}{*}{ No. } & \multirow{2}{*}{ Distribusi Data Variabel } & \multicolumn{2}{c}{ Statistik } & \multirow{2}{*}{ Status } \\
\hline 1. & Kelas $P B I$ & 10,357 & 11,07 & Normal \\
2. & Kelas sinektik & 9,000 & 11,07 & Normal \\
\hline
\end{tabular}




\section{Efektivitas Pembelajaran Menulis Cerpen dengan Model PBI}

Untuk membuktikan bahwa pembelajaran menulis cerpen dengan menggunakan model PBI memenuhi kriteria keefektifan, maka dilakukan uji perbedaan dua rata-rata dan uji ketuntasan belajar berdasarkan hasil tes akhir kelas yang dikenai perlakuan pembelajaran menulis cerpen dengan model PBI.

\section{Uji perbedaan dua rata-rata (Uji t)}

Uji t dimaksudkan untuk membuktikan bahwa terdapat perbedaan keefektifan pembelajaran menulis cerpen pada siswa kelas VIII A setelah diberi perlakuan model PBI. Pengujian skor tes awal dan skor tes akhir kelas yang dikenai pembelajaran menulis cerpen dengan model PBI dilakukan untuk mengetahui perbedaan rata-rata siswa kelas tersebut. Kelas tersebut pada awalnya memiliki kesamaan kemampuan, khususnya dalam hal menulis cerpen. Oleh karena itu, perlu dibuktikan apakah terdapat perubahan kemampuan pada kelas sampel tersebut melalui uji t. Uji $t$ dilakukan dengan kriteria $\mathrm{H}_{\mathrm{o}}$ diterima apabila $-\mathrm{t}_{(1-1 / 2 \mathrm{a})(\mathrm{n} 1+\mathrm{n} 2-2)} \leq \mathrm{t} \leq \mathrm{t}_{(1-1 / 2)(\mathrm{n} 1+\mathrm{n} 2-}$ 2) dengan taraf signifikansi $5 \%$ dan $\mathrm{dk}=\left(\mathrm{n}_{1}+\mathrm{n}_{2}-2\right)$.

Rata-rata skor tes awal kelas yang melaksanakan pembelajaran dengan menggunakan model PBI adalah 68,853. Rata-rata skor tes akhir kelas yang melaksanakan pembelajaran dengan menggunakan model PBI adalah 77,15. Setelah data tersebut diuji $\mathrm{t}$, diperoleh $\mathrm{t}_{\text {hitung }}=-4,108, \mathrm{t}_{(1-1 / 2 \mathrm{a})(\mathrm{n} 1+\mathrm{n} 2-2)}= \pm 2,00$, dan $\mathrm{dk}=66$. Dengan demikian, $\mathrm{t}_{\text {hitung }}$ berada pada daerah penolakan $\mathrm{H}_{\mathrm{o}}$ yang berarti terdapat perbedaan rata-rata tes awal dan tes akhir kelas yang melaksanakan pembelajaran dengan menggunakan model PBI yaitu skor tes akhir (setelah mendapat perlakuan) lebih baik daripada skor tes awal (sebelum diberi perlakuan). Hasil uji t post-test kelas yang melaksanakan pembelajaran dengan menggunakan model PBI dapat dilihat pada Tabel 13 berikut.

Tabel 13 Hasil uji t pretest-posttest kelas PBI

\begin{tabular}{cccc}
\hline $\mathrm{K}$ & Rata-rata & $\mathrm{t}_{\text {hitung }}$ & $\mathrm{t}_{(1-1 / 2 \mathrm{a})(\mathrm{n} 1+\mathrm{n} 2-2)}$ \\
\cline { 1 - 2 } Problem Based Instrucion (PBI) awal & 68.853 & & \multirow{2}{*}{ $\pm 2,00$} \\
Problem Based Instrucion (PBI) akhir & 77.147 & $-4,108$ & $\pm 2,00$ \\
\hline
\end{tabular}

\section{Uji ketuntasan belajar}

Uji ketuntasan belajar dilakukan untuk mengetahui apakah hasil belajar siswa kelas VIII A (kelas PBI) dapat mencapai ketuntasan belajar secara individual atau tidak. Siswa dikatakan tuntas apabila mampu mencapai kriteria ketuntasan minimal (KKM) individual yang sudah ditetapkan, yaitu sebesar 75. Dengan demikian, secara statistik siswa dikatakan tuntas apabila rata-rata hasil belajar kognitifnya lebih dari sama 
dengan 75. Kriteria pengujian yang digunakan, yaitu $H_{o}$ ditolak $\left(H_{a}\right.$ diterima) jika $t_{\text {hitung }} \geq \mathrm{t}_{(1-1 / 2 \alpha)(\mathrm{n}-1)}$ dengan taraf signifikansi $5 \%$. $\mathrm{H}_{\mathrm{o}}$ berarti belum mencapai ketuntasan belajar individual.

Tabel 14 Hasil uji ketuntasan belajar PBI

\begin{tabular}{ccccc}
\hline $\mathrm{K}$ & Rata-rata & $\mathrm{t}_{\text {hitung }}$ & $\mathrm{t}_{\text {tabel }}$ & Kriteria \\
\hline Problem Based Instruction (PBI) & 77,15 & 1,538 & 2,03 & Tuntas
\end{tabular}

Berdasarkan uji ketuntasan belajar kelas yang melaksanakan pembelajaran menulis cerpen dengan menggunakan menggunakan model PBI, diketahui rata-rata nilai tes akhir siswa sebesar 77,15 , sedangkan berdasarkan perhitungan uji $t$ menunjukkan $t_{h i t u n g}=1,538$ dan $t_{\text {tabel }}$ $=\mathrm{t}_{(0,95: 31)}=2,03$. Dengan demikian, $\mathrm{t}_{\text {hitung }}>-\mathrm{t}_{\text {tabel }}$ sehingga dapat disimpulkan bahwa kelas yang melaksanakan pembelajaran menulis cerpen dengan menggunakan menggunakan model PBI sudah mencapai ketuntasan belajar individual.

\section{Efektivitas Pembelajaran Menggunakan Model Sinektik}

Untuk membuktikan bahwa pembelajaran menulis cerpen dengan menggunakan model sinektik memenuhi kriteria keefektifan, maka dilakukan uji perbedaan dua rata-rata dan uji ketuntasan belajar berdasarkan hasil tes akhir kelas yang dikenai perlakuan pembelajaran menulis cerpen dengan model sinektik

\section{Uji perbedaan dua rata-rata $(\mathrm{Uji} t)$}

Uji $t$ bertujuan untuk membuktikan bahwa terdapat perbedaan keefektifan pembelajaran menulis cerpen pada siswa kelas VIII B setelah diberi perlakuan model sinektik. Pengujian skor tes awal dan skor tes akhir kelas yang dikenai pembelajaran menulis cerpen dengan model sinektik dilakukan untuk menegtahui perbedaan rata-rata siswa kelas tersebut. Uji t dilakukan dengan kriteria $\mathrm{H}_{\mathrm{o}}$ diterima apabila $\quad-\mathrm{t}_{(1-1 / 2 \mathrm{a})(\mathrm{n} 1+\mathrm{n} 2-2)} \leq \mathrm{t} \leq \mathrm{t}_{(1-}$ $1 / 2 \mathrm{a})(\mathrm{n} 1+\mathrm{n} 2-2)$ dengan taraf signifikansi $5 \%$ dan $\mathrm{dk}=\left(\mathrm{n}_{1}+\mathrm{n}_{2}-2\right)$.

Berdasarkan hasil perhitungan uji $\mathrm{t}$, diperoleh $\mathrm{dk}=58$, $\mathrm{t}_{\mathrm{hitung}}=-5,727$, dan $t_{(1-1 / 2 \alpha)(n 1+n 2-2)}= \pm 2,00$ sehingga $t_{\text {hitung }}$ berada di daerah penerimaan $H_{a}$ yang berarti terdapat perbedaan rata-rata tes awal dan tes akhir kelas yang melaksanakan pembelajaran dengan menggunakan model sinektik. Dengan demikian, $\mathrm{t}_{\text {hitung }}$ berada pada daerah penolakan $\mathrm{H}_{\mathrm{o}}$ yang berarti terdapat perbedaan rata-rata tes awal dan tes akhir kelas yang melaksanakan pembelajaran dengan menggunakan model sinektik yaitu skor tes akhir (setelah mendapat perlakuan) lebih baik dari pada skor tes awal (sebelum diberi perlakuan). Hasil uji $\mathrm{t}$ post-test kelas yang melaksanakan 
pembelajaran dengan menggunakan model sinektik dapat dilihat pada Tabel 15 berikut.

Tabel 15 Hasil uji t post-test kelas sinektik

\begin{tabular}{|c|c|c|c|}
\hline & $\mathrm{K}$ Rata-rata & thitung & $\mathrm{t}(1-1 / 2 \mathrm{a})(\mathrm{n} 1+\mathrm{n} 2-2)$ \\
\hline Sinektik awal & 7 & & \\
\hline Sinektik akhir & $8 \overline{3}, 4$ & $-5,727$ & $\pm 2,00$ \\
\hline
\end{tabular}

\section{Uji ketuntasan belajar}

Uji ketuntasan belajar dilakukan untuk mengetahui apakah hasil belajar siswa kelas VIII B (kelas sinektik) dapat mencapai ketuntasan belajar secara individual atau tidak. Siswa dikatakan tuntas apabila mampu mencapai kriteria ketuntasan minimal (KKM) individual yang sudah ditetapkan, yaitu sebesar 75. Dengan demikian, secara statistik siswa dikatakan tuntas apabila rata-rata hasil belajar kognitifnya lebih dari sama dengan 75 .

Tabel 16 Hasil uji ketuntasan belajar kelas sinektik

\begin{tabular}{rrrrl}
\hline Kelas & Rata-rata & thitun & t tabel & Kriteria \\
\hline Sinektik & 83,4 & 8,119 & 2,04 & Tuntas \\
\hline
\end{tabular}

Berdasarkan uji ketuntasan belajar kelas yang melaksanakan pembelajaran menulis cerpen dengan menggunakan model sinektik, diketahui rata-rata nilai tes akhir siswa sebesar 83,4, sedangkan berdasarkan perhitungan uji $\mathrm{t}$ menunjukkan $\mathrm{t}_{\text {hitung }}=8,119$ dan $\mathrm{t}_{\text {tabel }}=\mathrm{t}_{(0,95: 31)}=2,04$. Dengan demikian, $t_{\text {hitung }}<t_{\text {tabel }}$ sehingga dapat disimpulkan bahwa kelas yang melaksanakan pembelajaran menulis cerpen dengan menggunakan model sinektik sudah mencapai ketuntasan belajar individual.

Tabel 17 Hasil observasi kelas PBI

\begin{tabular}{clccccc}
\hline No. & \multicolumn{1}{c}{ Aspek penilaian } & Sriteria & & \\
& & $\begin{array}{c}\text { Sangat } \\
\text { Kurang }\end{array}$ & Kurang & Cukup & Baik & $\begin{array}{c}\text { Sangat } \\
\text { Baik }\end{array}$ \\
\hline 1. & Keterbukaan & 0 & $0 \%$ & $38.2 \%$ & $52.9 \%$ & $8.8 \%$ \\
2. & Ketekunan belajar & 0 & $0 \%$ & $21 \%$ & $64.7 \%$ & $14.7 \%$ \\
3. & Kerajinan & 0 & $0 \%$ & $32.4 \%$ & $61.8 \%$ & 6 \\
4. & Tenggang rasa & 0 & $0 \%$ & $29.4 \%$ & $58.8 \%$ & $12 \%$ \\
5. & Kedisiplinan & 0 & $0 \%$ & $14.7 \%$ & $79.4 \%$ & 6 \\
6. & Kerja sama & $0 \%$ & $0 \%$ & $32.4 \%$ & $58.8 \%$ & $\%$ \\
7. & Ramah dengan teman & $0 \%$ & $0 \%$ & $9 \%$ & $88.2 \%$ & $2.9 \%$
\end{tabular}




\begin{tabular}{rlrrrrr} 
8. & Hormat pada guru & $0 \%$ & $0 \%$ & $35.3 \%$ & $64.7 \%$ & $0 \%$ \\
9. & Kejujuran & $0 \%$ & $0 \%$ & $24 \%$ & $68 \%$ & $9 \%$ \\
10. & Kepedulian & $0 \%$ & $0 \%$ & $35.3 \%$ & $61.8 \%$ & $2.9 \%$ \\
11. & Tanggung jawab & $0 \%$ & $0 \%$ & $29.4 \%$ & $67.6 \%$ & $2.9 \%$ \\
\hline
\end{tabular}

\section{Hasil Pembelajaran Model PBI dalam Menulis Cerpen}

Berdasarkan hasil penelitian, hasil pembelajaran menulis cerpen dengan model PBI sudah efektif. Hal ini dibuktikan dari hasil belajar siswa. Nilai tertinggi yang diperoleh siswa adalah 91, dan nilai terendah adalah 55, dengan rata-rata 77,147. Rerata hasil analisis data tersebut termasuk pada rentang 70-84, dan termasuk kategori baik.

Selain mengggunakan uji gain untuk menentukan kriteria keefektifan suatu proses pembelajaran, kriteria yang kedua yaitu menggunakan. Uji ketuntasan belajar dilakukan untuk mengetahui apakah hasil belajar siswa kelas VIII A (kelas PBI) dapat mencapai ketuntasan belajar secara individual atau tidak. Siswa dikatakan tuntas apabila mampu mencapai KKM individual yang sudah ditetapkan, yaitu sebesar 75. Dengan demikian, secara statistik siswa dikatakan tuntas apabila rata-rata hasil belajar kognitifnya lebih dari sama dengan 75 . Kriteria pengujian yang digunakan, yaitu $\mathrm{H}_{\mathrm{o}}$ ditolak $\left(\mathrm{H}_{\mathrm{a}}\right.$ diterima) jika $\mathrm{t}_{\text {hitung }} \geq \mathrm{t}_{(1-1 / 2 \alpha)(\mathrm{n}-1)}$ dengan taraf signifikansi $5 \% . \mathrm{H}_{\mathrm{o}}$ berarti belum mencapai ketuntasan belajar individual.

Tabel 18 Hasil uji ketuntasan belajar kelas PBI

\begin{tabular}{ccccl}
\hline Kelas & Rata-rata & Thitung & tabel & Kriteria \\
\hline Problem Based Instruction (PBI) & 77,15 & 1,538 & 2,03 & Tuntas \\
\hline
\end{tabular}

Tabel 19 Hasil penilaian model PBI

\begin{tabular}{clccc}
\hline No. & \multicolumn{1}{c}{ Aspek yang Dinilai } & Skor & Bobot & Skor X Bobot \\
\hline 1. & Kesesuaian tema & 5 & 2 & 10 \\
2. & Penceritaan alur & 4 & 4 & 16 \\
3. & Pemilihan latar & 5 & 4 & 20 \\
4. & Penggunaan sudut pandang Penggunaan & 5 & 2 & 10 \\
5. & gaya bahasa Penggambaran tokoh dan & 5 & 2 & 10 \\
6. & penokohan Kepaduan unsur-unsur dalam & 4 & 4 & 16 \\
7. & cerpen & 4 & 2 & 8 \\
& NILAI & & & 9 \\
\hline
\end{tabular}


Tabel 21 Hasil penilaian model sinektik

\begin{tabular}{llccc}
\hline No. & \multicolumn{1}{c}{ Aspek yang Dinilai } & Skor & Bobot & Skor X Bobot \\
\hline 1. & Kesesuaian tema & 4 & 2 & 8 \\
2. & Penceritaan alur & 3 & 4 & 12 \\
3. & Pemilihan latar & 3 & 4 & 12 \\
4. & Penggunaan sudut pandang & 4 & 2 & 8 \\
5. & Penggunaan gaya bahasa & 4 & 2 & 8 \\
$6 . \quad$ Penggambaran tokoh dan & 3 & 4 & 12 \\
7. & penokohan Kepaduan unsur-unsur & 4 & 2 & 8 \\
& dalam cerpen & & & 69 \\
& NILAI & & & \\
\hline
\end{tabular}

\section{Keefektifan Pembelajaran Menulis Cerpen dengan Model Sinektik}

Pada bagian ini dijelaskan proses pembelajaran menulis cerpen dengan model sinektik dan hasil pembelajaran menulis cerpen dengan model sinektik. Perlakuan (treatment) yang diberikan kepada kepada kelas VIII B berupa pembelajaran menggunakan model sinektik dilakukan sesuai dengan RPP yang dibuat berdasarkan sintakmatik model sinektik. Dengan model pembelajaran ini, siswa diajak untuk berpikir kreatif, memecahkan masalah dengan beranalogi atau mengandaikan diri.

Tahap pertama pembelajaran menulis cerpen dengan model sinektik mendeskripsikan kondisi saat ini. Pada tahap pertama ini tujuan pembelajaran yang perlu ditekankan adalah untuk membangkitkan kreativitas siswa khususnya dalam menulis cerpen dengan cara guru meminta siswa untuk mengamati keadaan di sekitarnya dan mendeskripsikannya. Sebelumnya siswa diberi sebuah contoh tayangan cerita pengalaman seseorang kemudian siswa diminta mengamati keadaan di lingkungan sekitarnya (rumah maupun sekolah).

Tahap selanjutnya siswa menggunakan analogi langsung dengan bimbingan dari guru. Analogi langsung merupakan perbandingan sederhana antara dua objek atau konsep. Fungsi proses ini adalah untuk mentransposikan suatu keadaan nyata pada keadaan lain dalam rangka memperoleh pandangan baru atau ide atau masalah baru. Kemudian, siswa diminta memilih salah satu analogi tersebut. Tahap selanjutnya a dalah siswa dibimbing guru untuk menulis analogi yang telah mereka pilih pada tahap ke dua. Sampai tahap ini, siswa sudah menulis cerpennya. Kemudian berlanjut ke tahap berikutnya berdasarkan tahap ke dua dan tahap ketiga di atas, siswa diminta mengemukakan dua konflik atau pertentangan. Pada tahap ini siswa menentukan klimaks dari cerpennya. Tahap selanjutnya 
siswa mengemukakan analogi langsung berdasarkan konflik yang telah dipilih pada tahap sebelumnya. Ini merupakan tahapan anti klimaks atau peleraian dari cerpen. Dan yang terakhir siswa diajak kembali ke tugas dan permasalahan yang sebenarnya menggunakan analogi terakhir/analogi pada tahap sebelumnya.

Tahapan-tahapan yang telah dilalui siswa tersebut dapat digunakan untuk menuliskan cerpen yang ingin mereka tulis. Dan proses analogi yang dilakukan siswa bisa membuat mereka lebih menyatu dengan peristiwa yang akan mereka tulis karena mereka berandai-andai berada di dalam peristiwa di dalam cerpen yang akan mereka tulis tersebut sehingga cerpen yang dihasilkan lebih baik dari sebelum-sebelumnya.

Selama kegiatan pembelajaran berlangsung, peneliti melakukan pengamatan atau observasi terhadap tingkah laku siswa. Hasil observasi pada kelas sinektik selama pembelajaran menulis cerita pendek menggunakan model pembelajaran sinektik disajikan pada tabel berikut.

Tabel 22 Hasil observasi sinektik

\begin{tabular}{clccccc}
\hline No. & \multicolumn{1}{c}{ Aspek penilaian } & \multicolumn{3}{c}{ Kriteria (\%) } & & \\
& & $\begin{array}{c}\text { Sangat } \\
\text { Kurang }\end{array}$ & Kurang & Cukup & Baik & $\begin{array}{c}\text { Sangat } \\
\text { Baik }\end{array}$ \\
\hline 1. & Keterbukaan & $0 \%$ & $0 \%$ & $20 \%$ & $60 \%$ & $20 \%$ \\
2. & Ketekunan belajar & $0 \%$ & $0 \%$ & $13.3 \%$ & $80.0 \%$ & $6.7 \%$ \\
3. & Kerajinan & $0 \%$ & $0 \%$ & $20 \%$ & $66.7 \%$ & $13.3 \%$ \\
4. & Tenggang rasa & $0 \%$ & $0 \%$ & $20 \%$ & $73.3 \%$ & 7 \\
& & & & & & \\
5. & Kedisiplinan & $0 \%$ & $0 \%$ & $0 \%$ & $86.7 \%$ & $13 \%$ \\
6. & Kerja sama & $0 \%$ & $0 \%$ & $23.3 \%$ & $66.7 \%$ & $10 \%$ \\
7. & Ramah dengan teman & $0 \%$ & $0 \%$ & $0 \%$ & $66.7 \%$ & $33.3 \%$ \\
8. & Hormat pada guru & $0 \%$ & $0 \%$ & $0 \%$ & $73.3 \%$ & $27 \%$ \\
9. & Kejujuran & $0 \%$ & $0 \%$ & $16.7 \%$ & $80 \%$ & $3 \%$ \\
10. & Kepedulian & $0 \%$ & $0 \%$ & $23.3 \%$ & $70 \%$ & $6.7 \%$ \\
11. & Tanggung jawab & $0 \%$ & $0 \%$ & $36.7 \%$ & $50 \%$ & $13 \%$ \\
\hline
\end{tabular}

Setelah dilaksanakan analisis dapat diketahui bahwa model Problem Based Instruction (PBI) dan model sinektik sangat efektif dalam pembelajaran menulis cerpen. Akan tetapi, jika dilihat perbandingannya maka model sinektik lebih efektif dibandingkan dengan PBI. 


\section{KESIMPULAN}

Berdasarkan hasil analisis data dan pembahasan maka dapat disimpulkan sebagai berikut. Model Problem Based Instruction (PBI) maupun model sinektik sangat efektif dalam pembelajaran menulis cerpen. Hasilnya diketahui nilai rata-rata tes akhir siswa dengan menggunakan kedua model tersebut di atas nilai KKM sehingga dapat disimpulkan bahwa kelas yang melaksanakan pembelajaran menulis cerpen dengan menggunakan menggunakan model PBI maupun sinektik mencapai ketuntasan belajar individual. Akan tetapi, dari hasil analisis nilai rata-rata tes akhir siswa, nilai KKM lebih tinggi pada kelas yang menggunakan model sinektik dibandingkan dengan model PBI.

\section{E. DAFTAR PUSTAKA}

Aminuddin. (2009). Pengantar apresiasi karya sastra. Bandung: Sinar Baru Algensindo.

Arikunto, S. (2006). Prosedur penelitian suatu pendekatan praktik. Jakarta: Rineka Cipta.

Esten, M. (2000). Teori kesusasteraan: Pengantar teori dan sejarah. Yogyakarta: Kanisius.

Gie, T. L. (2002). Terampil mengarang. Yogyakarta: Andi.

Harjito. (2002). Sastra dan manusia: Teori dan terapannya. Semarang: IKIP PGRI.

Hernowo. (2004). Mengikat makna untuk remaja. Bandung: MLC.

Ismail. (2011). Pembelajaran sastra di SMP. Semarang: PT Andalas.

Komaidi, D. (2007). Aku bisa menulis (Panduan praktis menulis kreatif lengkap). Yogyakarta: Sabda Media.

Laksana, P. (2009). Panduan praktis mengarang-menulis. Semarang: Aneka Ilmu.

Nurimaini. (2008). Pembelajaran model sinektik. Yogyakarta: Kanisius.

Rahmanto, B. (2000). Metode pengajaran sastra. Yogyakarta: Kanisius. 
Rosa, H. T. ( 2 002). Teknik menulis cerpen. Cairo: Makalah Pelatihan Jurnalistik dan Kepenulisan ICMI Pusat.

Suprijono. (2009). Langkah-langkah pembelajaran problem based instruction. Yogyakarta: Andi.

Tarigan, H. G. (2008). Menulis sebagai suatu keterampilan berbahasa. Bandung: Penerbit Angkasa.

Trianto. (2009). Pengajaran model problem based instruction. Yogyakarta: Andi.

Wagiran. (2009). Keterampilan berbahasa. Jakarta: Rineka Cipta. 